\title{
Motivations and Future Intentions in Sport Event Volunteering: A Systematic Review
}

\author{
Salvador Angosto ${ }^{1, *(\mathbb{C}}$, Hyejin Bang ${ }^{2, *}$, Gonzalo A. Bravo ${ }^{3}{ }^{\mathbb{C}}$, Arturo Díaz-Suárez ${ }^{1}(\mathbb{C}$ \\ and José María López-Gullón ${ }^{1}$ \\ 1 Department of Physical Activity and Sport, Faculty of Sports Sciences, University of Murcia, \\ 30720 Santiago de la Ribera, Spain; ardiaz@um.es (A.D.-S.); luchamurcia@um.es (J.M.L.-G.) \\ 2 Department of Counseling, Recreation, and School Psychology, Florida International University, \\ Miami, FL 33199, USA \\ 3 College of Physical Activity and Sport Sciences, West Virginia University, Morgantown, WV 26506, USA; \\ gonzalo.bravo@mail.wvu.edu \\ * Correspondence: salvador.a.s@um.es (S.A.); bangh@fiu.edu (H.B.)
}

check for updates

Citation: Angosto, S.; Bang, H.;

Bravo, G.A.; Díaz-Suárez, A.;

López-Gullón, J.M. Motivations and Future Intentions in Sport Event Volunteering: A Systematic Review. Sustainability 2021, 13, 12454. https:/ / doi.org/10.3390/su132212454

Academic Editor: Ermanno C. Tortia

Received: 11 October 2021

Accepted: 8 November 2021

Published: 11 November 2021

Publisher's Note: MDPI stays neutral with regard to jurisdictional claims in published maps and institutional affiliations.

Copyright: (C) 2021 by the authors. Licensee MDPI, Basel, Switzerland. This article is an open access article distributed under the terms and conditions of the Creative Commons Attribution (CC BY) license (https:/ / creativecommons.org/licenses/by/ $4.0 /)$.

\begin{abstract}
Understanding the future intentions of individuals who are part of a sport organization is a critical step for the success and the accomplishment of the goals of such organizations, particularly for sporting events that highly depend on the work of volunteers. Therefore, it is important to determine which factors motivate an individual to volunteer, as well as the intentions volunteers have to continue volunteering for sporting events or other similar organizations. This study conducted a systematic review of literature on studies that have examined the motivation and future intentions of volunteering in sporting events. The PRISMA methodology was used to develop this review. It included 30 studies from 2007 to 2020, and all the studies examined these two constructs using different types of quantitative methodologies. Moreover, most of these studies were conducted by scholars in the United States and Australia, and the VMS-ISE was the most used instrument for collecting data. Many of the studies did not include a theoretical framework relating motivation and future intentions to other constructs. The results of this systematic review provide new insights regarding the state of studies that have examined future intentions related to volunteering in sporting events, particularly regarding how to plan future investigations of volunteers' motivation and future intention in the context of sporting events.
\end{abstract}

Keywords: systematic review; sporting events; volunteers; motivation; behavior intentions

\section{Introduction}

Volunteers play a critical role in the sustainability of many service organizations in today's society. The sport event sector particularly depends largely on volunteers, as they play an important role in providing direct services, which is critical to the success of sporting events [1,2]. Volunteers offer a broad range of skills and abilities, from general assistance (e.g., stuffing bags and handing out water) to skill-specific assistance (e.g., medical support) [3,4], to helping sport event organizations sustain event operations and services [1]. The non-monetary value of volunteer efforts and hours spent in sporting events produces a great source of economic benefit to the host organization [5].

Although volunteers provide substantial contributions to, and provide true economic values for, the event organization while furthering the community hosting the sport events, volunteering at sport events tends to be episodic, which makes it difficult to determine volunteers' continued dedication to the community. Especially, volunteers at sport megaevents (SMEs) such as the FIFA World Cup, the Olympics, and the Paralympic Games are engaged in temporary episodic volunteering activities due to the episodic nature of SMEs. In other words, the one-off and fixed-term nature of SMEs may attract different 
individuals to volunteer work, indicating that they are motivated for different reasons to those of regular volunteers, who are involved on a more continuous basis [6].

Despite the episodic volunteering at SMEs with definite completion points, individuals' positive volunteering experiences at SMEs can increase their intention to continue volunteering for future sport events or other types of events in the community, building a long-term volunteer base for future endeavors [1]. Therefore, a deeper understanding of SME volunteer motivations is a key task when developing successful strategies not only for recruiting and training, but also for satisfying and retaining SME volunteers [5].

\subsection{Motivations of Volunteering at Sport Events}

Volunteering motivations have been widely studied, and various multi-dimensional models have been proposed [7]. Most efforts to understand the motivations behind volunteering have taken on a functional approach, applying the functional theory [8]. The functional theory proposes that individuals may perform the same actions to serve a variety of functions [9]. Applying functional theory to the question of the motivations of volunteers, Clary et al. [10] developed the Volunteer Functional Inventory (VFI), which consists of six motivational functions: values, understanding, social, career, protective, and enhancement. This scale, while assessing general motivations for volunteering, has been extensively used in the sports context [11-16]. Kim et al. [17] modified the VFI scale by developing the Modified Volunteer Functions Inventory for Sports (MVFIS), which is a smaller version of the VFI and is also applied to the sports context. Farrell et al. [18] argued that the motivations of sport event volunteers varied depending on the type of event. They thus designed the Special Event Volunteer Motivation Scale (SEVMS) and identified four categories within the volunteers participating in a women's curling championship in Canada: purposive, solidary, external traditions, and commitments. The SEVMS has been used by several studies [19-23].

Later, Giannoulakis et al.'s [24] study of the Athens 2004 Olympic Games (OG) developed the Olympic Volunteer Motivation Scale (OVMS), which includes three categories: Olympic related, egoistic, and purposive. This scale specifically reflected the attributes of volunteering in the OG [25]. To assess the motivations of volunteering at SMEs, Bang and Chelladurai [5] developed the Volunteer Motivation Scale for International Sporting Events (VMS-ISE) using the 2002 FIFA World Cup volunteer sample, identifying six different motivational factors: expression of values, patriotism, interpersonal contacts, career orientation, personal growth, and extrinsic rewards. The VMS-ISE has been further revised by Bang and Ross [26] and Bang et al. [27], adding one more factor, "Love of sport", to the scale. The VMS-ISE was validated to also be used in small-scale sporting event (SSE) contexts by adopting the item wording of the patriotism factor for a "community involvement" factor [27]. Numerous studies have used VMS-ISE to evaluate the motivations of volunteers at various types of sport events [1,28-35].

\subsection{Volunteer Motivations and Future Intention to Continue Volunteering}

One of the most influential theories in explaining the link between volunteers' motivations and their intentions to continue volunteering in the future, social exchange theory, assumes that social behavior or relationships are the results of an exchange process [36]. Individuals tend to perform cost-benefit analyses, attempting to gain more rewards than risks through a behavior. When the risks outweigh the rewards, the behavior will be abandoned. That is, if individuals value their volunteer work as involving higher rewards than costs, they are more likely to continue volunteering. Conversely, if their time and efforts in the volunteer work are less rewarding than they expected, they would be less likely to volunteer again.

Empirical evidence shows that volunteers who are satisfied with their experience are willing to volunteer for future events or in other settings. Hyde et al.'s [37] study of a charity sport event setting found that volunteer motivation factors, such as socializing/enjoyment and financial support, had positive influences on satisfaction and organizational commit- 
ment, which contributed to future volunteering intention not only for the future charity, event but also for other events. Similarly, a recent study by Bang et al. [1] at the Rio 2016 Olympic and Paralympic Games indicated that expression of values, love of sport, and the career orientation of the VMS-ISE motivations were positively associated with volunteers overall satisfaction, which led to their future volunteer intention. Accordingly, previous studies have supported the main concept underlying social exchange theory, suggesting that individuals' intention to continue volunteering may be affected by the extent to which their motivations are fulfilled during their volunteer activities at the sporting event.

\subsection{Purpose of the Study}

There have been numerous attempts to develop measurement instruments for sport event volunteer motivations, with extended efforts to explore the influence of volunteer motivations on key components of the voluntary experience, such as commitment and retention [6]. The majority of the studies highlight that volunteers who find benefits related to their primary motivations are most likely to be satisfied with their volunteering experience and to continue to volunteer $[1,10]$. This study conducted a systematic review of quantitative studies that have evaluated the motivations of volunteers in sport events, and reviewed all available research linking volunteers' motivations to their intention to continue volunteering.

There is little methodological research relating to the performance of systematic reviews of volunteer motivation. In one of the very few studies, Kim [2] conducted a systematic review on volunteer motivation in the specific context of sport events, examining 33 eligible studies that measured motivation in sport events between 1995 and 2015. Despite the existence of this recent study, it is necessary to update the review of volunteer motivation studies in the sport event context due to the increasing number of studies on sport event volunteer motivation that have been published in the past six years. Moreover, limited attention has been paid to a quantitative synthesis of the direction and magnitude of the relationship between sport event volunteer motivation and future volunteering intentions. A clear and comprehensive overview of the findings of all relevant studies on sport event volunteer motivations and future intentions would contribute to not only more accurate conclusions on the link, but also evidence-based volunteer management practices.

\section{Materials and Methods}

\subsection{Inclusion and Exclusion Criteria}

For this review, we included empirical studies published in peer-reviewed journals, excluding dissertations and abstracts. Databases from grey literature, including evaluation reports, annual reports, articles in non-peer-reviewed journals, and other channels of publication, were removed. The inclusion criteria for the articles were: (i) journal articles; (ii) publications in English, Spanish, or Portuguese; (iii) motivation in sport volunteering; (iv) future intentions of sport event volunteers; and (v) articles focused on sporting events but not sport organizations. The exclusion criteria were formulated as (i) congress proceedings, book chapters, books, or other types of publications; (ii) articles that did not measure volunteer motivation; (iii) theoretical studies, qualitative approaches or reviews; (iv) articles in a language other than English, Spanish, or Portuguese; (v) articles that did not measure future intentions; and (vi) duplicate articles. It is important to note that future intentions should be evaluated after the volunteering experience, with some studies, such as Rozmiarek et al.'s [38], assessing the motivation for volunteering in a future sports event.

\subsection{Search Strategy}

The review used a search strategy that established three categories of search terms: (i) volunteering; (ii) other factors; and (iii) type of volunteering. The search strategy used a combination of the search terms with OR within each category, as presented in Table 1. Different electronic databases, including Web of Science, Scopus, SPORTDiscus (EBSCO), PsycINFO (Ovid), ABI/Inform (Ovid), and MEDLINE (PubMed), were selected to provide 
comprehensive coverage of research areas addressing this interdisciplinary study, including sports science, marketing, social sciences, and psychology. The search was conducted from 22 February 2021 to 20 August 2021.

Table 1. Database search strategy.

\begin{tabular}{|c|c|}
\hline Search Category & Search Terms \\
\hline Volunteering & $\begin{array}{l}\text { "Sport Volunteer" OR sport volunteer * OR } \\
\text { "Sport volunteer *" OR Sport Voluntar * OR } \\
\text { "Sport Voluntar *" OR sport volunteerism } \\
\text { OR volunteering }\end{array}$ \\
\hline Type of volunteering & $\begin{array}{l}\text { Motivation OR motives OR motiv * OR } \\
\text { Satisfaction OR “intention to continue" OR } \\
\text { permanence OR retention OR Commitment OR } \\
\text { Engagement OR participation OR recruitment } \\
\text { OR management OR maintenance } \\
\text { event OR "Sport Event" OR sport event OR } \\
\text { sporting event OR club OR “sport club" OR } \\
\text { sport club OR sport organization OR } \\
\text { organization OR “sport organization" }\end{array}$ \\
\hline Combination & 1 and 2 and 3 \\
\hline
\end{tabular}

Note: *: truncation. Search for the exposed root.

Following the PRISMA methodology [39], eligible articles were identified. The initial database search resulted in 26,295 articles, which were reduced to 5140 articles after the removal of duplicates. Two reviewers screened independently using the titles, then the abstracts, and finally the full texts using the inclusion and exclusion criteria. There were no discrepancies between the two reviewers, and the number of studies finally selected for qualitative synthesis was 32 (see Figure 1). Three articles were discarded at the abstract level because the full text could not be obtained. The reference lists of the articles initially selected were also used to find other frequently cited academic works that did not appear in various databases.

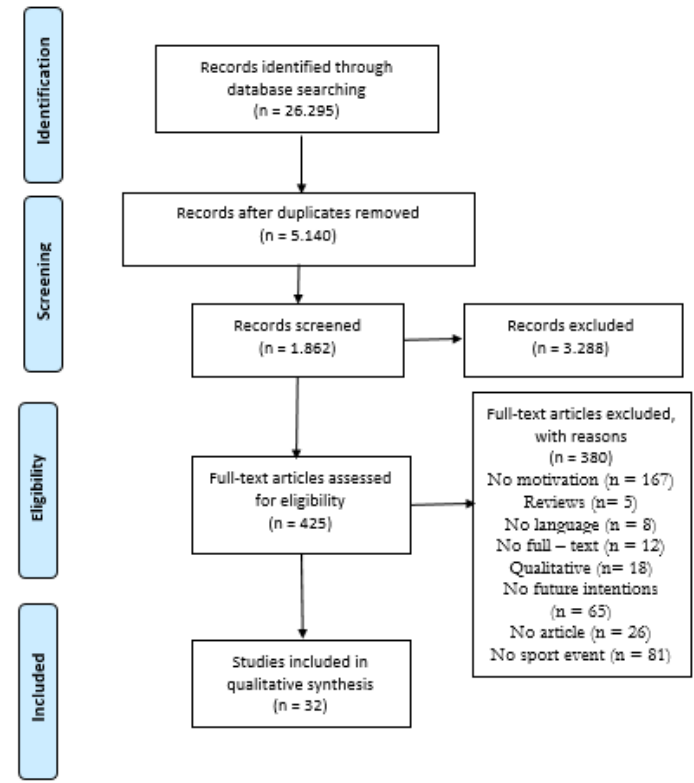

Figure 1. PRISMA flow diagram Source: Moher et al. [38].

\subsection{Assessment of Methodological Quality}

The assessment of the methodological quality followed a two-step process. First, two reviewers independently evaluated each study to identify whether the inclusion and exclusion criteria previously described were met. Then, researchers conducted a 
second evaluation and used a 20-item appraisal tool, known as CONSORT, developed by Schultz et al. [40] and adapted by Angosto et al. [41]. The CONSORT tool was used to assess the extent to which studies in this review met the criteria described in Table S1. During this step, the two reviewers independently examined the different sections of the study (i.e., introduction, methods, results, etc.) and rated each item of the CONSORT tool with " 1 " if the study satisfactorily met the criteria established with this tool, and with " 0 " if the study did not meet the criteria. Any disagreements between the two reviewers were resolved by discussion, which led the reviewers to find a consensus.

\subsection{Data Extraction and Synthesis}

The data were collected in a Microsoft Excel sheet and included the following information: (i) year of publication, country of publication, name of journal; (ii) research data, such as the size of the event, the type of the event, the procedure used to collect data, the methods used, other variables analyzed, and the type of the statistical analysis; (iii) research findings, including the main results of the dimensions and other relevant outcomes. The size of the events was classified as sport mega-events (SMEs) and small-scale events (SSEs). The subcategory of the events was based on the classification proposed by Müller [42] for mega-events and Getz and Page [43] for non-mega-events. The methods focused on the procedure followed for the completion of the questionnaire, whether it was online, face-to-face, or both, as well as whether the scale was self-administered or not. The main results were the averages of the different dimensions of the scale used and the items that were generally best and worst rated by the volunteers. The different dimensions of the instruments were analyzed following the relationship between the motivational factors of each type of instrument proposed by Kim et al. [31]. Other relevant results were marked as those related to the comparative analysis according to some variables or the application of multiple regressions.

\section{Result}

\subsection{Methodological Quality Assessment}

Among the 32 studies included in this review, 6 studies received 15 points or higher out of a possible total of 20 points [1,11,34,44-46]. The rest of the articles scored between 10 and 15 points. No studies had a score below 10 points (see Table S1). Notably, none of the studies analyzed performed the sample size calculation required for the generalization of the results to a wider population, which could be due to the fact that all the studies utilized convenience samples.

\subsection{Scope of Research}

A total of 32 academic studies evaluated the motivation and future intentions for volunteer participation in sporting events. These articles were published between 2007 and 2021, with half of the studies published in the last five years (Table S2 identifies the specific data for each study). Table 2 shows the location (country) of the studies and authors. The studies were conducted by a total of 66 researchers from 15 different countries. Most of the authors were based in the United States (28.8\%), followed by Australia (15.2\%), Brazil $(10.6 \%)$ and Norway (7.6\%). Other studies included in this review were from authors in Canada and Korea (6.1\% each), the United Kingdom, China and Switzerland (4.5\% each), Germany and Singapore (3.0\% each), and finally, Hong Kong, Malaysia, New Zealand, and Scotland (1.5\% each).

Regarding the locations (country) in which the studies were conducted, eight studies were performed in universities in the United States $(25.0 \%)$, followed by five studies in universities in Australia (15.6\%), and then three studies in Brazil, Canada, China and Korea (9.4\% each). Four more studies were conducted in universities in Norway and the United Kingdom (6.3\% each), and one study was conducted each in Germany, Singapore, and Switzerland (3.1\% each). 
Table 2. Study and author location by country.

\begin{tabular}{ccc}
\hline Country & Study Location & Author Location \\
\cline { 2 - 3 } & $\mathbf{N ~ ( \% )}$ & $\mathbf{N}(\%)$ \\
\hline United States & $8(25.0)$ & $19(28.8)$ \\
Australia & $5(15.6)$ & $10(15.2)$ \\
Brazil & $3(9.4)$ & $7(10.6)$ \\
Canada & $3(9.4)$ & $4(6.1)$ \\
Korea & $3(9.4)$ & $4(6.1)$ \\
China & $3(9.4)$ & $3(4.5)$ \\
Norway & $2(6.3)$ & $5(7.6)$ \\
United Kingdom & $2(6.3)$ & $3(4.5)$ \\
Germany & $1(3.1)$ & $2(3.0)$ \\
Singapore & $1(3.1)$ & $2(3.0)$ \\
Switzerland & $1(3.1)$ & $3(4.5)$ \\
Hong Kong & - & $1(1.5)$ \\
Malaysia & - & $1(1.5)$ \\
New Zealand & - & $1(1.5)$ \\
Scotland & - & $1(1.5)$ \\
Total & 32 & $66^{*}$ \\
\hline
\end{tabular}

Note: Study location is the institution location of the first article's author. Author location is the institution location of each author listed in each article. * One author listing articles in two different countries' institutions.

Regarding the year of publication, Figure 2 shows that 2019 was the year with the highest number of publications $(n=5)$, followed by 2015 and 2017, with four studies each, while 2016, 2018, and 2020 each listed three studies. Two studies were published in 2009, 2014 and 2021, and one study in 2007, 2011, 2012, and 2013 each. It is important to highlight that between 2017 and 2020, the number of studies doubled compared to the previous 10 years. Finally, regarding the type of publication, Table 3 shows that the 32 studies included were published in 26 different journals from several areas of study. The area of events showed the highest number of publications, comprising $25.0 \%$, followed by sports and volunteering $(15.6 \%$ each), and tourism represented $12.5 \%$ of the studies. To a lesser extent, three studies (9.4\%) were published in the area of psychology, one in the area of hospitality (3.1\%), and one in the area of leisure (3.1\%). Five studies (15.6\%) were published in other journals that less commonly focused on the area of volunteering and sporting events. The journal Event Management had the highest number of published studies $(n=6)$ and Voluntas contained two studies. The remaining journals had only one publication each.

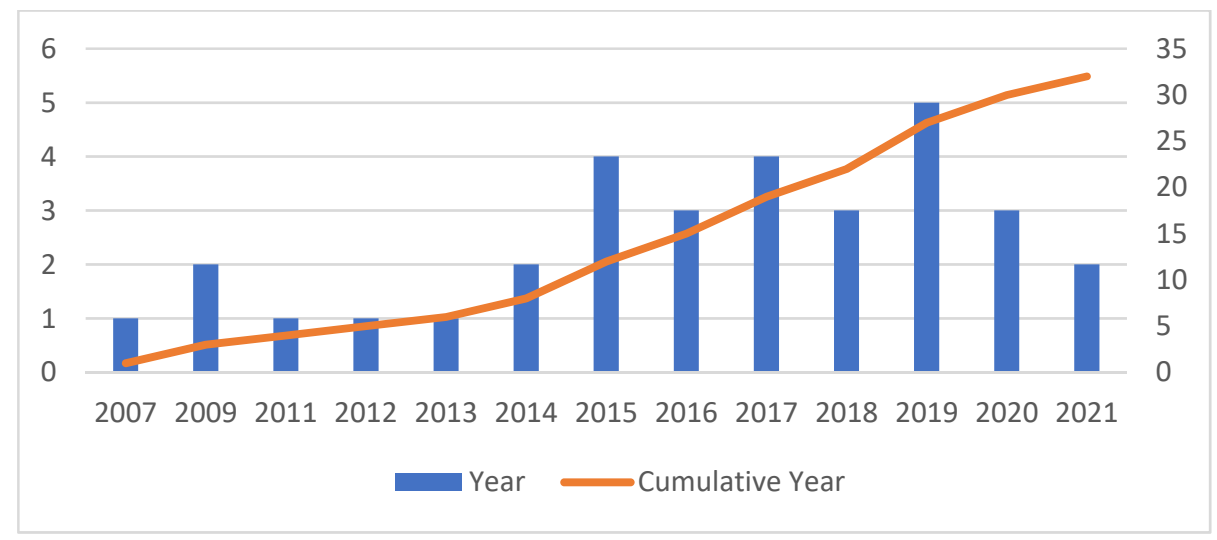

Figure 2. Cumulative and annual published frequency of studies. 
Table 3. Field and journal of the reviewed studies.

\begin{tabular}{cccc}
\hline Field & Journal & N & $\%$ \\
\hline Event (8) & Event Management & 6 & 18.8 \\
& International Journal of Event and Festival Management & 1 & 3.1 \\
& International Journal of Hospitality and Event Management & 1 & 3.1 \\
\hline \multirow{2}{*}{ Sport (5) } & International Journal of Sport Management and Marketing & 1 & 3.1 \\
& Journal of Applied Sport Management & 1 & 3.1 \\
& Journal of Sport Management & 1 & 3.1 \\
& Sport Management Review & 1 & 3.1 \\
& Sport, Business and Management: An international journal & 1 & 3.1 \\
\hline \multirow{3}{*}{ Volunteering (5) } & Voluntas & 2 & 6.3 \\
& International Review on Public and Nonprofit Marketing & 1 & 3.1 \\
& Nonprofit and Voluntary Sector Quarterly & 1 & 3.1 \\
& Voluntary Sector Review & 1 & 3.1 \\
\hline Tourism (4) & Journal of Destination Marketing \& Management & 1 & 3.1 \\
& Journal of Policy Research in Tourism, Leisure and Events & 1 & 3.1 \\
& Journal of Tourism and Leisure Research & 1 & 3.1 \\
& Tourism Management & 1 & 3.1 \\
\hline \multirow{2}{*}{ Psychology (3) } & Journal of Community Psychology & 1 & 3.1 \\
& Journal of Organizational Psychology & 1 & 3.1 \\
& Journal of Sport Psychology & 1 & 3.1 \\
\hline Hospitality (1) & International Journal of Contemporary Hospitality Management & 1 & 3.1 \\
\hline Leisure (1) & Leisure/Loisir & 1 & 3.1 \\
\hline Other (5) & Holos & 1 & 3.1 \\
& Indiana AHPERD & 1 & 3.1 \\
& Organizações em contexto & 1 & 3.1 \\
& Revista Pensamento Contemporâneo em Administração & 1 & 3.1 \\
& Sustainability & 3.1 \\
\hline & & &
\end{tabular}

\subsection{Key Measurement Scale}

Table 4 shows the different scales used to evaluate studies in sport volunteers' motivation. Nine different types of scales were identified in the included studies analyzed, and $25.0 \%$ of the studies did not specify the model used to assess the volunteers' motivation. The most commonly used scale was the Volunteer Motivation Scale for International Sporting Events (VMS-ISE), developed by Bang and Ross [26], with a total of ten studies analyzed. The Volunteer Functions Inventory (VFI) scale by Clary et al. [10] was the second most used survey, with six studies. The Special Event Volunteer Motivation Scale (SEVMS) by Farrell et al. [18], the Special Volunteer Motivation Scale (SVMS) by Monga [47], and the Volunteer Motivation Scale (VMS) by Knoke and Prensky [48] were included in two studies each. Other scales used in one study only included the Kano method, developed by Kano et al. [49], the Intrinsic Motive Fulfillment (IMF) by Boezeman and Ellemers [50], the Charity Sport Event motivation (CSE) by Filo et al. [51] and a Volunteer Motivation Scale based on self-determination theory, proposed by Millette and Gagné [52].

Table 4. Key measurement scales of the studies.

\begin{tabular}{ccc}
\hline Survey & $\mathbf{N}$ & $\%$ \\
\hline Volunteer Motivation Scale-International Sporting Events (VMS-ISE) & 10 & 31.3 \\
Motivation but not specified model & 8 & 25.0 \\
Volunteer Functions Inventory (VFI) & 6 & 18.8 \\
Volunteer Motivation Scale (VMS) & 2 & 6.3 \\
Charity Sport Event motivation (CSE) & 1 & 3.1 \\
Intrinsic Motive Fulfillment (IMF) & 1 & 3.1 \\
Kano method & 1 & 3.1 \\
Motivation based on self-determination theory & 1 & 3.1 \\
Special Events Volunteer Motivation Scale (SEVMS) & 1 & 3.1 \\
Special Volunteer Motivation Scale (SVMS) & 1 & 3.1 \\
\hline
\end{tabular}




\subsection{Theoretical Basis}

The different theories used in the studies analyzed in this review are presented in Table 5. Our review identified a total of ten theories, with one study using two different theories. Fourteen studies did not specify any theory. Ryan and Deci's [53] self-determination theory was the most commonly applied theory, appearing in four studies. Then, it was the theory of planned behavior by Ajzen [54], which was found in three studies, while the social exchange theory $[36,55]$ and the theory of sport fan involvement $[56,57]$ were used in two studies each. Other theories used were functional theory [10], motivation hygiene theory [58], motivation theory [59,60], theory of attitude change [61], modernization theory [62,63], psychological contract theory [64] and basic psychological need theory [65].

Table 5. Theories used by the reviewed studies.

\begin{tabular}{ccc}
\hline Theoretical Framework & $\mathbf{N}$ & $\mathbf{\%}$ \\
\hline No specific theory & 15 & 45.2 \\
Self-determination theory [53] & 4 & 12.9 \\
Theory of planned behavior [54] & 3 & 9.7 \\
Social exchange theory [36,55] & 2 & 6.5 \\
Theory of sport fan involvement [56,57] & 2 & 6.5 \\
Functional theory [10] & 1 & 3.2 \\
Modernization theory [62,63] & 1 & 3.2 \\
Motivation theory [59,60] & 1 & 3.2 \\
Motivation hygiene theory [58] & 1 & 3.2 \\
Psychological contract theory [64] & 1 & 3.2 \\
Basic psychological need theory [65] & 1 & 3.2 \\
Theory of attitude change [61] & 1 & 3.2 \\
\hline
\end{tabular}

\subsection{Method and Sample}

The total sample of volunteers included in the 32 studies was 42,233, with a minimum of 70 volunteers and a maximum of 11,451 volunteers. This represented an average of 1319.8 volunteers per event (see Table S2). All of the included studies used quantitative methodologies. According to the type of event, $50.0 \%$ of the studies were conducted at mega-events and $46.9 \%$ at non-mega-events, while one study did not specify the type of event as its study context (Table 6). Regarding the scale of the event, most were classified as giga-events, major-events, regional-events and local-events, all four types with six studies each, followed by mega-events with four studies, and there were three studies conducted at regional and local events.

Table 6. Key constructs used in the reviewed studies.

\begin{tabular}{cccccc}
\hline Variable & $\mathbf{N}$ & \% & Variable & $\mathbf{N}$ & \% \\
\hline Type of event & & & Event country & 2 & 6.1 \\
Mega-event & 16 & 50.0 & Australia & 4 & 12.1 \\
Small-scale & 15 & 46.9 & Brazil & 4 & 12.1 \\
Not specified & 1 & 3.1 & Canada & 5 & 15.2 \\
Scale of event & & & China & 1 & 3.0 \\
Giga-event & 6 & 18.8 & Germany & 2 & 6.1 \\
Mega-event & 4 & 12.5 & Korea & 1 & 3.0 \\
Major event & 6 & 18.8 & New Zealand & 2 & 6.1 \\
Regional event & 6 & 18.8 & Norway & 1 & 3.0 \\
Regional event/Local event & 3 & 9.4 & Switzerland & 5 & 15.2 \\
Local event & 6 & 18.8 & United States & 6 & 18.2 \\
Not specified & 1 & 3.1 & Method & & \\
Type of volunteer & & & Mixed Survey & 4 & 12.5 \\
Event volunteer & 27 & 84.4 & Online Survey & 16 & 50.0 \\
Students & 4 & 12.5 & Paper-Based Survey & 11 & 34.4 \\
Disabled volunteer & 1 & 3.1 & Post or Email Survey & 1 & 3.1 \\
\hline
\end{tabular}


Regarding the location of the event, the results show that these events took place in 11 different countries. The United States was the country with the highest number of events (six events), followed by the United Kingdom and China (five events), and Brazil and Canada with four events each. Two events took place in Australia, Korea, and Norway. Finally, one event each took place in Germany, New Zealand, and Switzerland.

Most of the studies used event-specific volunteering as the study sample (Table 6), representing $84.4 \%$ of the total; $12.5 \%$ of the studies considered only university volunteering, while one study only evaluated volunteering with disabilities. Regarding the method used, half of the studies used an online questionnaire, one-third (34.4\%) used a paper and pencil questionnaire, $12.5 \%$ used a mixed method of survey collection including online and paper-based, and one study collected data through email.

\subsection{Key Constructs and Results Related to Motivation}

Table 7 shows the different constructs used in the included studies. There were 22 constructs that appeared 107 times in the studies. Of these, motivation and future intentions appeared in all 32 studies. The next most repeated construct was satisfaction, which was included in 15 studies, followed by commitment with 4 studies, emotional exhaustion and work climate in 3 studies, and attitude and experience in 2 studies. Other constructs included were affordance, altruism, attractiveness, autonomy, basic psychological needs, belief in organization values, connectedness, encouraging others, expectation, participation, recognition rewards, skills, travel planned behavior, and value internalization.

Table 7. Key constructs used in the reviewed studies.

\begin{tabular}{ccc}
\hline Key Constructs & N & \% \\
\hline Motivation & 32 & 29.9 \\
Future intentions & 32 & 29.9 \\
Satisfaction & 15 & 14.0 \\
Commitment & 4 & 3.7 \\
Emotional exhaustion & 3 & 2.8 \\
Work climate & 3 & 2.8 \\
Attitude & 2 & 1.9 \\
Experience & 2 & 1.9 \\
Affordance & 1 & 0.9 \\
Altruism & 1 & 0.9 \\
Attractiveness & 1 & 0.9 \\
Autonomous & 1 & 0.9 \\
Belief in organization values & 1 & 0.9 \\
Connectedness & 1 & 0.9 \\
Encouraging others & 1 & 0.9 \\
Expectation & 1 & 0.9 \\
Participation & 1 & 0.9 \\
Basic psychological needs & 1 & 0.9 \\
Recognition-rewards & 1 & 0.9 \\
Skills & 1 & 0.9 \\
Travel planned behavior & 1 & 0.9 \\
Value internalization & 1 & 0.9 \\
TOTAL & 107 & \\
\hline
\end{tabular}

As for the main results in the motivation of volunteers participating in sporting events (see Table S3 and Figure 3), expression of values was the most significant motive in 18 of the studies analyzed, followed by love of sport, appearing in 14 studies, career orientation in 4 studies, and interpersonal contacts or social in 4 studies. Additionally, community involvement or patriotism, personal growth, and intrinsic motivation were identified as significant motivational factors in three studies, and Olympic function were rated highly in two studies each. Other motives that appeared in at least one study were leisure, cause, skills, or excitement in general. On the other hand, among the motivational profiles with 
the lowest scores, the extrinsic rewards factor stood out in seven studies, followed by the career motive, with four studies, and protective motive, with three studies. Two studies showed low scores on social motives, external influence, and availability. The motives altruism, personal growth, reference group, transactional, and variety were among the lowest-scoring motives in one study.

\begin{tabular}{|c|c|}
\hline \multicolumn{2}{|c|}{ MOTIVATION } \\
\hline High value & Low value \\
\hline $\begin{array}{l}\text { - } \quad \text { Related Values (18) } \\
\text { - } \quad \text { Related Love of sport (14) } \\
\text { - } \quad \text { Related Social and Career (4) } \\
\text { - Related Patriotism, Personal growth and } \\
\text { - } \text { Intrinsic motivation (3) } \\
\text { - } \quad \text { Related Olympic function (2) } \\
\text { - Cause, Skills, Excitement (1) }\end{array}$ & 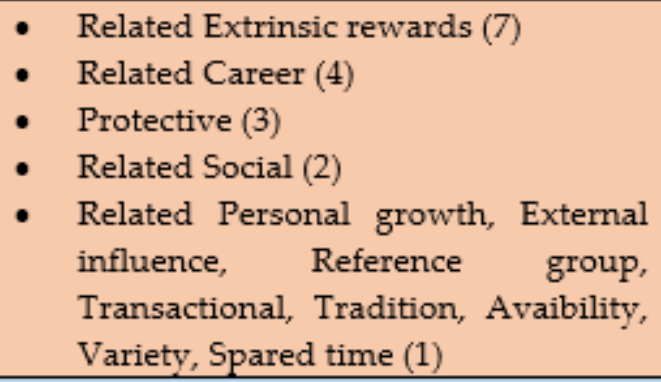 \\
\hline \multicolumn{2}{|c|}{ FUTURE INTENTIONS } \\
\hline Influenced by* & Value \\
\hline $\begin{array}{l}\text { - } \text { Related Values (6) } \\
\text { - Related Love of Sport and Social (5) } \\
\text { - Related Personal growth, Community } \\
\text { involvement, Intrinsic motivation (4) } \\
\text { - Related Career, Understanding (3) } \\
\text { - } \quad \text { Related Extrinsic rewards, Leisure, } \\
\text { Cause, Variety (1) }\end{array}$ & $\begin{array}{ll}\text { - } & \text { Moderate (1) } \\
\text { - } & \text { Moderate-High (2) } \\
\text { - } & \text { High (5) }\end{array}$ \\
\hline
\end{tabular}

Figure 3. Summary of motivation score and its influence on future intentions.

\subsection{Relationship between Motivation and Future Intentions}

Among the studies that have shown evidence of this relationship, Ahn [43] identified that leisure, egoistic, and purpose motives had a statistically significant influence on future intentions, with connectedness as a moderating variable. Bang et al. [66] showed that the most important factors influencing future intentions were volunteer commitment and the motives of community involvement and extrinsic rewards. Other studies that used the VMS-ISE motives showed that all factors except extrinsic rewards were positively associated with future intentions [67]. Hallmann and Harms [68] reported that expression of values and personal growth were the motives with the strongest influence on future intentions. Another study found that only the interpersonal contacts factor had a positive and significant influence on future intentions [69]. Bang et al. [1] found that expression of values, love of sport, patriotism, and career orientation had significant and direct effects on future intentions. In addition, differences existed between volunteers with repeated event experience and volunteers who participated for the first time.

Kim et al. [15] found that all VFI factors had a significant influence on satisfaction, which acted as a moderating variable between motivation and future intentions. In a sample of student volunteers at sporting events, Johnson et al. [14] found that career and social motives predicted future intentions. However, if satisfaction was included as a predictor variable only, career motive predicted future intentions. Chiu et al. [70] found that sport and event-related motives and cause motives had a significant influence on the future intentions of college sports volunteers. Günter et al. [12], using the VFI survey, identified that the understanding, social, enhancement, and good citizenship all influenced 
future intentions to return. Connection to sport has also been identified as an influential variable in future intentions [71].

Some studies found that intrinsic or altruistic motivation has indirect effects on future intentions [72,73]. Jiang et al. [74] and Sha [75] identified satisfaction as a mediating variable between intrinsic motivation and future intentions. Altruistic and variety motives were also shown to influence future intentions [76]. In contrast, some studies found no influence of any motivational factor on future intentions $[4,32,77]$. Two studies that conducted a segmentation of volunteering according to the motivational profile of volunteering found that there were significant differences between the different groups as regards future intentions [11,22]. Doherty [78] identified the existence of differences in volunteer future intentions according to type, planning volunteers, and on-site volunteers.

\section{Discussion}

The objective of this study was to conduct a systematic review to identify studies that have examined the motivations and future intentions of volunteers participating in sporting events. This review, unlike the previous ones carried out by Kim [2] and Kim and Cuskelly [79], provides an update of the last five years (2017 to 2021) of the scientific productivity regarding volunteering in sporting events. It also introduces the construct of future intentions as a key factor for volunteering and the success of sporting events. Moreover, this review expands the analysis to include more about the context of a sporting event, such as identifying the type of sporting event (i.e., mega-event or small-scale event), and the countries where these events took place, these being variables that were not previously considered in previous reviews. The results show that in recent years, there has been a sharp increase in the number of publications regarding motivation to volunteer in sporting events. Similarly, it was found that many more studies have focused on examining the motivation to volunteer in the context of SSEs. Additionally, most studies used the VMS-ISE scale when assessing volunteer's motivation. It was also found that many studies lacked a theoretical framework to provide support to their investigations. To facilitate the discussion of these findings, we organized them into six areas: (1) growth of publications and authors' location, (2) journal field of studies, (3) type, location of events and types of volunteers, (4) scales and types of questionnaires used in the studies, (5) theoretical framework used in the studies, and (6) a discussion regarding the constructs used in the studies.

Growth of publications and authors' location. The first study that evaluated the motivation and future intentions of volunteers in sporting events was published in 2007 by MacLean and Hamm [77]. This study was conducted at a golf championship in Canada. During the period from 2007 to 2016, the number of studies that evaluated these two constructs reached 15, while over the five years from 2017 to 2021, 17 studies were also published. This means that the number of studies published in this area has doubled, growing at a much faster pace when compared to the previous ten years.

In terms of the authors' location where the studies were conducted, this review confirms Kim's [2] previous finding that authors were mostly based in the United States. In Kim's [2] review, 70\% of the studies were from authors located in four countries, including the United States, Canada, Norway, and the United Kingdom. Similarly, Kim and Cuskelly [79] found that $60 \%$ of the authors were based in four countries (United States, Canada, Australia, and United Kingdom), but now Australia is among the top four. These findings revealed that there is a clear geographic concentration regarding authors who have studied the motivation and future intentions of volunteers in sporting events.

Journal field of study. Most of the studies (43.2\%) included in this review were published in journals that have a primary focus on the fields of events and sport. Other fields of study included tourism $(13.3 \%)$, volunteering $(13.3 \%)$, and psychology $(6.6 \%)$. This finding concurs with the results of previous reviews $[2,79]$.

In terms of the fields of study where these studies were published, tourism is without a doubt an important field, particularly when it relates to the impact of volunteering at 
sporting events. Large-scale sporting events, such as the OG, FIFA World Cups, Euro Cups, Super Bowls, etc., are considered the main drivers that contribute to promoting tourism and creating an economic impact for the city [80-82]. These events create enormous interest not only among sport fans, but also with the general population, who also want to be part of the experience of these events [83]. Therefore, having enough well-trained and motivated volunteers turns out to be critical not only to guarantee the success of a sporting event [84], but also for the tourist promotion of the city that hosts the event.

This review also shows that recent studies have examined the sustainability of volunteering in sporting events, specifically related to the impact and legacy of the event [85-87]. Lockstone-Binney and Ong [88] evaluated the contribution of tourism volunteering to the Sustainable Development Goals (SDGs). One way to assess the contribution of tourism volunteering to the SDGs is through the legacy that volunteers leave after participating in sporting events. Kim et al. [85] identified the legacy of volunteering at three levels, personal (personal growth, expansion of social connections, diversification of experiences), community, and national level (sense of community, increased awareness or reputation, tourism promotion, economic development). In terms of journals where the included studies were published, $81.2 \%$ of the studies were published in different journals; the remaining $18.8 \%$ of the articles were published in the Event Management journal.

Type, location of sport events and types of volunteers. Typically, most research on sport events has focused on examining SMEs, as these are the events that generate the greatest impact. The evaluation of the impacts of sport events has shown differences according to the scale of the event. SMEs tend to be more sporadic in nature (most of them take place every 2 or 4 years), and their venues vary. Conversely, SSEs tend to occur in larger numbers, be more frequent, and occur in the same place. Considering that the motivation of volunteers can vary according to the type of event in which they participate [18], and SSEs allow the more periodic and continuous involvement of volunteers, the retention and continuity of volunteers in sporting events seems to be of greater importance in SSEs, as they are more recurrent, contributing, in turn, to the growth of the event.

Regarding the type of event included in this review, the findings show a slightly larger number of studies that have examined SMEs (50.0\%) when compared to SSEs (46.9\%). Analyzing in greater depth, the SMEs were differentiated into three types following the recommendations of Müller [42]. This author established that events such as the Summer OG are labeled as "XXL or giga-event", while continental events such as the Asian Games, European Football, or the Winter OG are classified as an "XL or mega-event". Then, events such as the Commonwealth Games, the University Games, or any other large-sized events can be categorized as an "L or grand-event".

This review identified six studies that evaluated Summer OG $[1,11,15,33,45,69]$, three that evaluated the Winter OG $[44,73,76]$, and one that evaluated the European Football Championship [12]. Regarding SSEs, these were grouped based on the categories recommended by Getz and Page [43] when classifying tourist events. Thus, a "regional event" refers to any National Championship of a country, or a distinctive event at the national level, or any other event that does not meet the major event criteria set out by Müller [42]. On the other hand, a "local-event" refers to those that do not have national relevance and are more focused on the local community or neighborhood. Two studies evaluated multiple sporting events on these two scales [22,72].

Regarding the country where these events were held, $72.8 \%$ of the events took place in five countries, including the United States, the United Kingdom, China, Canada, and Brazil. The remaining 27.2\% took place in seven countries, including China, Australia, Norway, Korea, Germany, Switzerland, and New Zealand. In terms of the type of volunteers that participated in these studies, most of the studies (84.4\%) did not identify any characteristics for the volunteers, as they were called "event volunteers". In four studies (12.5\%), volunteers were classified as "university students" [13,14,70,89], and one study included "volunteers with disabilities" [45]. 
Scales and types of questionnaires. The most widely used instrument to determine the motivation of volunteers in sporting events was the VMS-ISE $[5,26]$, followed by the VFI questionnaire [10]. The greater use of the VMS-ISE scale can perhaps be explained via the fact that this was an instrument that was specifically developed for volunteering in sporting events that include factors such as extrinsic rewards or love of sport, which other scales, such as VFI or SEVMS, do not include.

Dickson et al. $[45,46,76]$ adopted a proprietary scale based on the SEVMS [18] questionnaire. Contrary to this review, Kim [2] found that the most used instrument was the SEVMS, followed by the VMS-ISE. Regarding the type of questionnaire, all the recent studies used an online questionnaire, while paper questionnaires mainly date from earlier studies when the use of the internet was not so widespread.

Theoretical Framework. Consistent with previous reviews, this review found that most studies lacked a sound theoretical basis and/or theoretical framework. For this review, half of the included studies do not link their research to any theoretical framework. A good theoretical base is essential to be able to connect the concepts that are evaluated, providing a base on which to build new knowledge and understand why different events may or may not occur $[90,91]$. The self-determination theory was the most used in four studies $[1,12,74,89]$, followed by the theory of planned behavior, with three studies $[46,67,70]$, and the theory of social exchange $[66,78]$ and the theory of involvement of the sports fan [32,68], with two studies each. Kim and Cuskelly [79] stated the limitations of the theory of planned behavior in sports volunteering when considering a linear decisionmaking process, which does not consider changes in future intentions and behavior change over time.

Constructs and Future Intentions. Several studies evaluate motivation and future intentions as isolated constructs without establishing any connection between them. Thus, they treat both constructs individually and describe the results separately. On the contrary, studies that relate motivation to future intentions find that different motivational factors affect future intentions. In other words, there is no single relevant motivational factor when it comes to significantly influencing the future intentions of the volunteer in sporting events.

Volunteer satisfaction was a construct widely used with motivation and future intentions. Satisfaction was considered in almost half of the studies. Commitment was another construct used to assess the degree of involvement of volunteers with the sporting event, since it can affect a volunteer's performance and motivation. Some studies have shown the influence of these constructs, either directly or as moderators of motivation, in future intentions. Bang et al. [66] found that engagement had a significant influence on future intentions, in addition to community involvement and extrinsic rewards motives. Satisfaction was a moderating variable of intrinsic motivation in the studies by Jiang et al. [74], Wu et al. [89] and Sha [75], while in the study by Johnson et al. [13] it had a direct effect on future intentions.

Finally, several studies have identified possible changes in the behavioral attitude of sport volunteers regarding their future intentions to continue volunteering. In a study conducted at the Vancouver 2010 Winter OG, Dickson et al. [76] found that $23.7 \%$ of the volunteers expected to volunteer more hours. Dickson et al. [45] found that $64.5 \%$ of the volunteers indicated that they wanted to dedicate more time to volunteering in the future. However, when analyzing the final results, there was a slight decrease in the intention to increase volunteering before the event (46\%) when compared to the post-event (44\%). Sand et al. [92] found that $40 \%$ of volunteers were interested in continuing volunteering in future sport events. However, Pereira and Cavalcante's [33,34] studies found that 78\% to $91 \%$ of volunteers wanted to continue volunteering in sport events. Finally, a more recent study showed that half of the volunteers wanted to continue with the same level of involvement in future events [46].

Although few studies have evaluated the direct incidence of motivation on the future intentions of volunteering, the different studies that did evaluate this incidence obtained very different results regarding the motivational factors that influence the future intention 
of volunteering. This diversity of results may be partially explained by the nature and type of sport events and by the socio-cultural context.

Previous studies have also identified the influence of intrinsic motivational factors such as values, contribution to the community, and love of sport $[1,12,14,15,66,68,69,71]$, as well as extrinsic motivational factors such as external rewards or professional development $[1,14,66,67]$. Ultimately, it is necessary to evaluate the effects of motivation and other constructs on future intentions, identifying the socio-cultural context as well as the type and nature of the event.

Finally, this study has several limitations. One limitation is that our systematic review did not provide the managerial implications for practitioners. Due to the different scales and assessment criteria, our focus was rather research-oriented, aiming to discuss the influences of volunteer motivation constructs on future intention rather than practical recommendations. Other limitations are related to publication bias, as journals generally publish those studies with positive and satisfactory results, and may ignore others whose results are not significant. Thirdly, there is limited access to databases and full-text articles because many journals are not indexed in the main databases, and studies related to the subject matter in non-indexed journals may be overlooked. Lastly, there is the lack of conceptual models that actually assess the influence of motivational factors on future intentions, as this does prevent us from really assessing the possible relationship between motivation and future intentions, since most studies measure it separately.

\section{Conclusions}

The main findings of this study confirm what has been reported in previous reviews. The interest in evaluating the motivation for volunteering in sporting events is a topic of significant importance for both researchers who have studied SMEs as well as those who have focused on SEEs. Based on the results of this study, it is suggested that scholars increase the number of studies of sporting events of lower hierarchy (i.e., annual regional sporting events as opposed to SMEs such the OG), since these turn out to be the most numerous, and are those that are carried out and repeated more frequently. In addition, the vast majority of research on volunteers' future intentions and motivation in sporting events has been concentrated in a few countries, making it necessary to expand these types of studies to other places and thus obtain more information on the motivation and future intentions of volunteers based on socio-cultural differences. The VMS-ISE has turned out to be the most complete and widely used instrument within the motivation of sports volunteering in recent years. It is important to note that most of the studies lack a theoretical basis to support these studies and results. Finally, considering that most of what we know about volunteers' motivation and future intentions has been derived in recent years, it is necessary to interrelate these constructs with other constructs to determine what additional factors, apart from those of the volunteer, encourage them to keep volunteering in the same events or other sporting events.

Supplementary Materials: The following are available online at https: / www.mdpi.com/article/10 .3390/su132212454/s1. Table S1 Methodological quality assessment; Table S2: Individual information of each study; Table S3: Information of the results and main findings of each study. References [93,94] are cited in the supplementary materials.

Author Contributions: Conceptualization, S.A. and H.B.; methodology, A.D.-S. and J.M.L.-G.; formal analysis, S.A. and G.A.B.; investigation, A.D.-S. and J.M.L.-G..; resources, S.A.; data curation, G.A.B.; writing-original draft preparation, S.A., H.B. and G.A.B.; writing-review and editing, H.B. and G.A.B.; visualization, S.A.; supervision, A.D.-S.; project administration, J.M.L.-G. All authors have read and agreed to the published version of the manuscript.

Funding: This research received no external funding.

Institutional Review Board Statement: The study was conducted according to the guidelines of the Declaration of Helsinki, and approved by the Ethics Committee of University of Murcia (protocol code 2056/2018 and 18 December 2018). 
Informed Consent Statement: Patient consent was waived due to this study is a review of the scientific literature and it does not involve patients.

Data Availability Statement: The data has been extracted from the information contained in each original article. The rest of the data can be found in the supplementary material of this study.

Conflicts of Interest: The authors declare no conflict of interest.

\section{References}

1. Bang, H.; Bravo, G.A.; Mezzadri, F.M.; Figuerôa, K.M. The impact of volunteer experience at sport mega-events on intention to continue volunteering: Multigroup path analysis. J. Community Psychol. 2019, 47, 727-742. [CrossRef]

2. Kim, E. A systematic review of motivation of sport event volunteers. World Leis. J. 2018, 60, 306-329. [CrossRef]

3. Ross, S.D.; Ferguson, A.; Herbet, D.L. Action in the event rent! Medical-legal issues facing the volunteer event physician. Sports Health 2013, 5, 304-345. [CrossRef]

4. Warner, S.; Newland, B.L.; Green, B.C. More than Motivation: Reconsidering Volunteer Management Tools. J. Sport Manag. 2011, 25, 391-407. [CrossRef]

5. Bang, H.; Chelladurai, P. Development and validation of the volunteer motivations scale for international sporting events (VMS-ISE). Int. J. Sport Manag. Mark. 2009, 6, 332-350. [CrossRef]

6. Hoye, R.; Cuskelly, G. The psychology of sport event volunteerism: A review of volunteer motives, involvement and behaviour. In People and Work in Events and Conventions: A Research Perspective; Baum, T., Deery, M., Hanlon, C., Lockstone-Binney, L., Smith, K., Eds.; CABI: Wallinford, UK, 2009; pp. 171-180. [CrossRef]

7. Pauline, G.; Pauline, J.S. Volunteer motivation and demographic influences at a professional tennis event. Team Perform. Manag. Int. J. 2009, 15, 172-184. [CrossRef]

8. Katz, D. The functional approach to the study of attitudes. Public Opin. Q. 1960, 24, 163-204. [CrossRef]

9. Snyder, M.; Clary, E.G.; Stukas, A.A. The functional approach to volunteerism. In Why We Evaluate: Functions of Attitudes; Maio, G.R., Olson, J.M., Eds.; Lawrence Erlbaum: Mahwah, NJ, USA, 2000; pp. 365-393.

10. Clary, E.G.; Snyder, M.; Ridge, R.D.; Copeland, J.; Stukas, A.A.; Haugen, J.; Miene, P. Understanding and assessing the motivations of volunteers: A functional approach. J. Personal. Soc. Psychol. 1998, 74, 1516-1530. [CrossRef]

11. Alexander, A.; Kim, S.B.; Kim, D.Y. Segmenting volunteers by motivation in the 2012 London Olympic Games. Tour. Manag. 2015, 47, 1-10. [CrossRef]

12. Güntert, S.T.; Neufeind, M.; Wehner, T. Motives for Event Volunteering: Extending the Functional Approach. Nonprofit Volunt. Sect. Q. 2015, 44, 686-707. [CrossRef]

13. Johnson, J.E.; Giannoulakis, C.; Felver, N.; Judge, L.W.; David, P.A.; Scott, B.F. Motivation, Satisfaction, and Retention of Sport Management Student Volunteers. J. Appl. Sport Manag. 2017, 9, 1-26. [CrossRef]

14. Johnson, J.E.; Giannoulakis, C.; Scott, B.F.; Felver, N.; Judge, L.W. Gender Differences in Motivation, Satisfaction, and Retention of Sport Management Undergraduate Student Volunteers. Ind. Assoc. Health Phys. Educ. Recreat. Dance 2016, 45, 40-45.

15. Kim, S.B.; Alexander, A.; Kim, D.Y. Volunteers' Motivation, Satisfaction, and Intention to Volunteer in the Future: The London 2012 Olympic Games. J. Tour. Leis. Res. 2019, 31, 431-454. [CrossRef]

16. Pierce, D.; Johnson, J.E.; Felver, N.; Wanless, E.; Judge, L.; State, B. Influence of Volunteer Motivations on Satisfaction for Undergraduate Sport Management Students. Glob. Sport Bus. J. 2014, 2, 63-72.

17. Kim, M.; Zhang, J.J.; Connaughton, D. Modification of the Volunteer Functions Inventory for application in youth sports. Sport Manag. Rev. 2010, 31, 25-38. [CrossRef]

18. Farrell, J.M.; Johnston, M.E.; Twynam, G.D. Volunteer Motivation, Satisfaction, and Management at an Elite Sporting Competition. J. Sport Manag. 1998, 12, 288-300. [CrossRef]

19. Khoo, S.; Engelhorn, R. Volunteer Motivations for the Malaysian Paralympiad. Tour. Hosp. Plan. Dev. 2007, 4, 159-167. [CrossRef]

20. Khoo, S.; Engelhorn, R. Volunteer Motivations at a National Special Olympics Event. Adapt. Phys. Act. Q. 2011, 28, 27-39. [CrossRef]

21. Khoo, S.; Surujlal, J.; Engelhorn, R. Motivation of volunteers at disability sports events: A comparative study of volunteers in Malaysia, South Africa and the United States. Afr. J. Phys. Health Educ. Recreat. Dance 2011, 9, 356-371.

22. Lockstone-Binney, L.; Holmes, K.; Smith, K.; Baum, T.; Storer, C. Are All My Volunteers Here to Help Out? Clustering Event Volunteers by Their Motivations. Event Manag. 2015, 19, 461-477. [CrossRef]

23. Strigas, A.; Jackson, E.N., Jr. Motivating volunteers to serve and succeed: Design and results of a pilot study that explores demographics and motivational factors in sport volunteerism. Int. Sport J. 2003, 7, 111-123.

24. Giannoulakis, C.; Wang, C.H.; Gray, D. Measuring Volunteer Motivation in Mega-Sporting Events. Event Manag. 2007, 11, 191-200. [CrossRef]

25. Giannoulakis, C.; Wang, C.H.; Felver, N. A modeling approach to sport volunteer satisfaction. Int. J. Event Festiv. Manag. 2015, 6, 182-199. [CrossRef]

26. Bang, H.; Ross, S.D. Volunteer Motivation and Satisfaction. J. Venue Event Manag. 2009, 1, 61-77.

27. Bang, H.; Alexandris, K.; Ross, S.D. Validation of the Revised Volunteer Motivations Scale for International Sporting Events (VMS-ISE) at the Athens 2004 Olympic Games. Event Manag. 2009, 12, 119-131. [CrossRef] 
28. Hallmann, K.; Downward, P.; Dickson, G. Factors influencing time allocation of sport event volunteers. Int. J. Event Festiv. Manag. 2018, 9, 316-331. [CrossRef]

29. Hallmann, K.; Zehrer, A.; Fairley, S.; Rossi, L. Gender and Volunteering at the Special Olympics: Interrelationships Among Motivations, Commitment, and Social Capital. J. Sport Manag. 2020, 34, 77-90. [CrossRef]

30. Kim, E.; Cuskelly, G.; Fredline, L. Motivation and Psychological Contract in Sport Event Volunteerism: The Impact of Contract Fulfilment on Satisfaction and Future Behavioral Intention. Event Manag. 2020, 24, 463-479. [CrossRef]

31. Kim, E.; Fredline, L.; Cuskelly, G. Heterogeneity of sport event volunteer motivations: A segmentation approach. Tour. Manag. 2018, 68, 375-386. [CrossRef]

32. Koutrou, N. The Impact of the 2010 Women's Rugby World Cup on Sustained Volunteering in the Rugby Community. Sustainability 2018, 10, 1030. [CrossRef]

33. Pereira, H.A.; Cavalcante, C.E. Medalha de ouro! Estudo sobre motivação no trabalho voluntário eventual nos Jogos Olímpicos no Rio de Janeiro. Organiz. Contex. 2018, 14, 177-206. [CrossRef]

34. Pereira, H.A.; Cavalcante, C.E. Eventual voluntary motivation in sports in youth school games in Brazil. Holos 2019,35 , e7411. [CrossRef]

35. Vetitnev, A.; Bobina, N.; Terwiel, F.A. The Influence of Host Volunteer Motivation on Satisfaction and Attitudes Toward Sochi 2014 Olympic Games. Event Manag. 2018, 22, 333-352. [CrossRef]

36. Thibaut, J.W.; Kelley, H.H. The Social Psychology of Groups; Routledge: London, UK, 2017. [CrossRef]

37. Hyde, M.K.; Dunn, J.; Wust, N.; Bax, C.; Chambers, S.K. Satisfaction, organizational commitment and future action in charity sport event volunteers. Int. J. Nonprofit Volunt. Sect. Mark. 2016, 21, 148-167. [CrossRef]

38. Rozmiarek, M.; Poczta, J.; Malchrowicz-Mo’sko, E. Motivations of Sports Volunteers at the 2023 European Games in Poland. Sustainability 2021, 13, 6406. [CrossRef]

39. Moher, D.; Liberati, A.; Tetzlaff, J.; Altman, D.G. The PRISMA Group. Preferred Reporting Items for Systematic Reviews and Meta-Analyses: The PRISMA Statement. PLoS Med. 2009, 6, e1000097. [CrossRef]

40. Schulz, K.F.; Altman, D.G.; Moher, D. CONSORT 2010 Statement: Updated guidelines for reporting parallel group randomised trials. BMJ 2010, 340, e332. [CrossRef] [PubMed]

41. Angosto, S.; García-Fernández, J.; Valantine, I.; Grimaldi-Puyana, M. The Intention to Use Fitness and Physical Activity Apps: A Systematic Review. Sustainability 2020, 12, 6641. [CrossRef]

42. Müller, M. What makes an event a mega-event? Definitions and sizes. Leis. Stud. 2015, 34, 627-642. [CrossRef]

43. Getz, D.; Page, S.J. Progress and prospects for event tourism research. Tour. Manag. 2016, 52, 593-631. [CrossRef]

44. Ahn, Y.J. Recruitment of volunteers connected with sports mega-events-A case study of the PyeongChang 2018 Olympic and Paralympic Winter Games. J. Destin. Mark. Manag. 2018, 8, 194-203. [CrossRef]

45. Dickson, T.J.; Darcy, S.; Benson, A. Volunteers with Disabilities at the London 2012 Olympic and Paralympic Games: Who, Why, and Will They Do It Again? Event Manag. 2017, 21, 301-318. [CrossRef]

46. Dickson, T.J.; Darcy, S.; Pentifallo, C. Ensuring volunteer impact, legacy and leveraging is not «fake news»: Lessons from the 2015 FIFA Women's World Cup. Int. J. Contemp. Hosp. Manag. 2020, 32, 683-705. [CrossRef]

47. Monga, M. Measuring Motivation to Volunteer for Special Events. Event Manag. 2006, 10, 47-61. [CrossRef]

48. Knoke, D.; Prensky, D. What Relevance Do Organization Theories Have for Voluntary Associations? Soc. Sci. Q. 1984, 65, 3-20.

49. Kano, N.; Seraku, N.; Takahashi, F.; Tsuji, S. Attractive quality and must-be quality. Hinshitsu J. Jpn. Soc. Qual. Control 1984, 14, 39-48.

50. Boezeman, E.; Ellemers, N. Intrinsic need satisfaction and the job attitudes of volunteers versus employees working in a charitable volunteer organization. J. Occup. Organ. Psychol. 2009, 82, 897-914. [CrossRef]

51. Filo, K.; Funk, D.C.; O’Brien, D. Examining motivation for charity sport event participation: A comparison of recreation-based and charity-based motives. J. Leis. Res. 2011, 43, 491-518. [CrossRef]

52. Millette, V.; Gagné, M. Designing volunteers' tasks to maximize motivation, satisfaction and performance: The impact of job characteristics on volunteer engagement. Motiv. Emot. 2008, 32, 11-22. [CrossRef]

53. Ryan, R.M.; Deci, E.L. Self-determination theory and the facilitation of intrinsic motivation, social development, and well-being. Am. Psychol. 2000, 55, 68-78. [CrossRef]

54. Ajzen, I. From Intentions to Actions: A Theory of Planned Behavior. In Action Control: From Cognition to Behavior; Kuhl, J., Beckmann, J., Eds.; Springer: New York, NY, USA, 1985; pp. 11-39. [CrossRef]

55. Homans, G.C. Social Behavior as Exchange. Am. J. Sociol. 1958, 63, 597-606. [CrossRef]

56. Laverie, D.A.; Arnett, D.B. Factors affecting fan attendance: The influence of identity salience and satisfaction. J. Leis. Res. 2000, 32, 225-246. [CrossRef]

57. Shank, M.D.; Beasley, F.M. Fan or fanatic: Refining a measure of sports involvement. J. Sport Behav. 1998, 21, 435-443.

58. Herzberg, F.I. Work and the Nature of Man; World Publishing Company: New York, NY, USA, 1966.

59. Herzberg, F.I. One More Time: How Do You Motivate Employees; Harvard Business Review: Boston, NJ, USA, 1968 ; Volume 65.

60. Maslow, A.H. Motivation and Personality, 3rd ed.; Pearson Education: London, UK, 1987.

61. Osgood, C.E.; Tannenbaum, P.H. The principle of congruity in the prediction of attitude change. Psychol. Rev. 1955, 62, 42-55. [CrossRef] 
62. Beck, U. From industrial society to the risk society: Questions of survival, social structure and ecological enlightenment. Theory Cult. Soc. 1992, 9, 97-123. [CrossRef]

63. Giddens, A. Modernity and Self-Identity: Self and Society in the Late Modern Age; Stanford University Press: Palo Alto, CF, USA, 2013.

64. Rousseau, D.M. Psychological and implied contracts in organizations. Empl. Responsib. Rights J. 1989, 2, 121-139. [CrossRef]

65. Deci, E.L.; Ryan, R.M. The "what" and "why" of goal pursuits: Human needs and the self-determination of behavior. Psychol. Inq. 2000, 11, 227-268. [CrossRef]

66. Bang, H.; Won, D.; Kim, Y. Motivations, Commitment, and Intentions to Continue Volunteering for Sporting Events. Event Manag. 2009, 13, 69-81. [CrossRef]

67. Bang, H.; Lee, C.S. The roles of large-scale sporting event volunteer motivations in predicting behavioural intention within the theory of planned behaviour. Int. J. Hosp. Event Manag. 2014, 1, 111-134. [CrossRef]

68. Hallmann, K.; Harms, G. Determinants of volunteer motivation and their impact on future voluntary engagement. Int. J. Event Festiv. Manag. 2012, 3, 272-291. [CrossRef]

69. Koutrou, N.; Pappous, A.N. Towards an Olympic volunteering legacy: Motivating volunteers to serve and remain-A case study of London 2012 Olympic Games volunteers. Volunt. Sect. Rev. 2016, 7, 269-291. [CrossRef]

70. Chiu, W.; Lee, Y.; Won, D. Bifactor analysis of motivation for charity sport event participation. Int. Rev. Public Nonprofit Mark. 2016, 13, 1-13. [CrossRef]

71. Mykletun, R.J.; Himanen, K. Volunteers at biking race events: Antecedents of commitment and intention to remain volunteering at future events. Sport Bus. Manag. Int. J. 2016, 6, 246-273. [CrossRef]

72. Cho, H.; Li, C.; Wu, Y. Understanding sport event volunteers' continuance intention: An environmental psychology approach. Sport Manag. Rev. 2020, 23, 615-625. [CrossRef]

73. Kim, B.J.; Kim, M.H.; Lee, J. Congruence Matters: Volunteer Motivation, Value Internalization, and Retention. J. Organ. Psychol. 2019, 19, 56-70. [CrossRef]

74. Jiang, K.; Potwarka, L.R.; Xiao, H. Predicting Intention to Volunteer for Mega-Sport Events in China: The Case of Universiade Event Volunteers. Event Manag. 2017, 21, 713-728. [CrossRef]

75. Sha, Q. Ensuring intentions to manage sport events through positive work climate and motivation: An empirical study on sports volunteers in China. J. Sport Psychol. 2021, 30, 97-111.

76. Dickson, T.J.; Benson, A.M.; Blackman, D.A.; Terwiel, A.F. It's All about the Games! 2010 Vancouver Olympic and Paralympic Winter Games Volunteers. Event Manag. 2013, 17, 77-92. [CrossRef]

77. MacLean, J.; Hamm, S. Motivation, commitment, and intentions of volunteers at a large Canadian sporting event. Leis. Lois. 2007, 31, 523-556. [CrossRef]

78. Doherty, A. The volunteer legacy of a major sport event. J. Policy Res. Tour. Leis. Events 2009, 1, 185-207. [CrossRef]

79. Kim, E.; Cuskelly, G. A systematic quantitative review of volunteer management in events. Event Manag. 2017, 21, 83-100. [CrossRef]

80. Malchrowicz-Mośko, E.; Poczta, J. A small-scale event and a big impact-Is this relationship possible in the world of sport? The meaning of heritage sporting events for sustainable development of tourism-Experiences from Poland. Sustainability 2018, 10, 4289. [CrossRef]

81. Rojas-Mendez, J.I.; Davies, G.; Jamsawang, J.; Duque, J.L.S.; Pipoli, G.M. Explaining the mixed outcomes from hosting major sporting events in promoting tourism. Tour. Manag. 2019, 74, 300-309. [CrossRef]

82. Pompurová, K.; Marčeková, R.; Šebová, L.; Sokolová, J.; Žofaj, M. Volunteer tourism as a sustainable form of tourism-The case of organized events. Sustainability 2018, 10, 1468. [CrossRef]

83. Vierhaus, C. The international tourism effect of hosting the Olympic Games and the FIFA World Cup. Tour Econ. 2019, 25, 1009-1028. [CrossRef]

84. Allen, J.B.; Shaw, S. 'Everyone rolls up their sleeves and mucks in': Exploring volunteers' motivation and experiences of the motivational climate of a sporting event. Sport Manag. Rev. 2014, 12, 79-90. [CrossRef]

85. Kim, H.; Choe, Y.; Kim, D.; Kim, J. For Sustainable Benefits and Legacies of Mega-Events: A Case Study of the 2018 PyeongChang Winter Olympics from the Perspective of the Volunteer Co-Creators. Sustainability 2019, 11, 2473. [CrossRef]

86. Kim, D.; Park, C.; Kim, H.; Kim, J. Determinants and Outcomes of Volunteer Satisfaction in Mega Sports Events. Sustainability 2019, 11, 1859. [CrossRef]

87. Koutrou, N.; Pappous, A.; Johnson, A. Post-Event Volunteering Legacy: Did the London 2012 Games Induce a Sustainable Volunteer Engagement? Sustainability 2016, 8, 1221. [CrossRef]

88. Lockstone-Binney, L.; Ong, F. The sustainable development goals: The contribution of tourism volunteering. J. Sustain. Tour. 2020, 1-17. [CrossRef]

89. Wu, Y.; Li, C.; Khoo, S. Predicting future volunteering intentions through a self-determination theory perspective. VOLUNTAS Int. J. Volunt. Nonprofit Organ. 2016, 27, 1266-1279. [CrossRef]

90. Sutton, R.I.; Staw, B.M. What theory is not. Adm. Sci. Q. 1995, 40, 371-384. [CrossRef]

91. Van Knippenberg, D. Advancing theory in organizational psychology. Organ. Psychol. Rev. 2011, 1, 3-8. [CrossRef]

92. Sand, T.S.; Strittmatter, A.M.; Hanstad, D.V. 2016 Winter Youth Olympic Games: Planning for a volunteer legacy. Int. J. Sport Manag. Mark. 2017, 17, 242-260. [CrossRef] 
93. Pereira, H.A.; Cavalcante, C.E.; Viana, J.C.; Sousa, R. Eventual voluntary motivation in sports: The F1 case. Rev. Pensam. Contep. Administ. 2019, 13, 34-48. [CrossRef]

94. Li, C.; Cho, H.; Wu, Y. Basic psychological need profiles and correlates in volunteers for a national sports event. VOLUNTAS Int. J. Volunt. Nonprofit Organ. 2021, in press. [CrossRef] 